\title{
Study of the mechanical behavior of a lightweight wood concrete
}

\author{
Bouabdallah M A
}

Department of Civil Engineering, National Polytechnic School of Oran, Algeria.

Corresponding Author: m-a.bouabdallah@enp-oran.dz

Received: 01-01-2020

Accepted: 17-04-2020

\begin{abstract}
Today, the development of building materials based on toxic or non-toxic industrial waste is a topical issue for the productive structures in industrialized countries. In this article, non-toxic wood waste (wood chips) is used to improve the characteristics of ordinary concrete (lightness, thermal insulation, acoustic absorption, rigidity under stresses, etc.) for the purpose of eventually developing light wood concrete. The present experimental study aims at conducting a comparative behavioral analysis between concretes based on non-toxic wood waste of natural origin on the one hand, and ordinary concrete on the other. In order to achieve this goal, a series of test pieces were made, with five different formulations. Four of them are lightweight wood-concretes obtained by the substitution of a volume of aggregates; the fifth formulation is ordinary concrete. A number of tests were carried out at the Construction Technical Control Laboratory at different ages, i.e. 7, 14, 21 and 28 days. Interesting results were obtained with respect to the evolution of the mechanical characteristics of light wood-concrete at early age. Some of these features, such as the long-term compressive strength of concrete, are essential parameters in civil engineering.
\end{abstract}

Key words: Concrete/Wood; Mass loss; Constraint/Deformation; Elastic modulus; Ultrasound.

\section{Introduction}

A number of studies on lightweight wood-concrete have been reported in the literature. The works of Bouabdallah et al. (2007, 2008), Taazount et al. (2011), Benmalek and Bederina (2014), Medjelekh et al. (2014), and Akkaoui (2015) are worth mentioning.

In addition, a large number of researchers have attempted to combine different materials with concrete to obtain a composite material with interesting features. Among these materials, it is worth mentioning glass (Zeghichi et al., 2005), waste concrete powder (WCP) (Yi Jiang et al., 2020); brick waste (Hadjoudja and Bederina, 2005), polypropylene fibers (Breitenbucher, 1998; Oredssen, 1997); polypropylene (Mohammadhosseini et al., 2020; Bouaziz, 2014); steel waste (Kalpana and Tayu, 2020) and many others.

In the field of construction, the reduction in self-weight, provided by lightweight concrete, may where appropriate prove to be technically and economically attractive, both for the restoration of old structures as well as for the construction of new ones. There is great potential for the development of systems composed of various composite materials. The combination of concrete and wood fibers from wood industry waste makes it possible to obtain lightweight woodconcrete (LWC) with interesting characteristics. The work presented in this article is a good example for the development of a composite material that has the properties of wood and concrete together. For the purpose of studying the characteristics of light wood concrete with respect to durability, it was decided to make a series of lightweight wood concrete (LWC) specimens with four formulations, at different percentages 


\section{Experimental study}

\section{$2.1 \quad$ Materials used}

Portland cement type II CEM II A 42.5 was used, with limestone gravel 0/3, 3/8 and 8/15 and siliceous sea sand $0 / 1$; wood waste and water were subsequently added.

Table 1. Cement

\begin{tabular}{|c|c|c|c|c|}
\hline Identification & Cement class & Type of addition in cement & Clinker \% & Density \\
\hline \hline CP & CPJ 42,5 & Pouzzolanique (6-20\%) & $80-94 \%$ & 3,1 \\
\hline
\end{tabular}

Table 2. Characteristic of the materials used

\begin{tabular}{|c|c|c|c|c|c|}
\hline \multicolumn{2}{|l|}{ Test } & Gravel 8/15 mm & Gravel 3/8 mm & Crushed sand & Sea sand \\
\hline \multicolumn{2}{|l|}{ Densities } & 2,735 & 2,727 & 2,714 & 2,642 \\
\hline \multicolumn{2}{|c|}{ Absorption Coefficients } & 1,52 & 1,75 & 2,65 & 2,11 \\
\hline \multicolumn{2}{|c|}{ Los Angeles } & \multicolumn{2}{|c|}{23,56} & - & - \\
\hline \multirow{2}{*}{$\begin{array}{l}\text { Sand Equivalent } \\
\text { Test }\end{array}$} & ESV & - & - & 76,86 & 72 \\
\hline & ESP & - & - & 70,53 & 67,69 \\
\hline
\end{tabular}

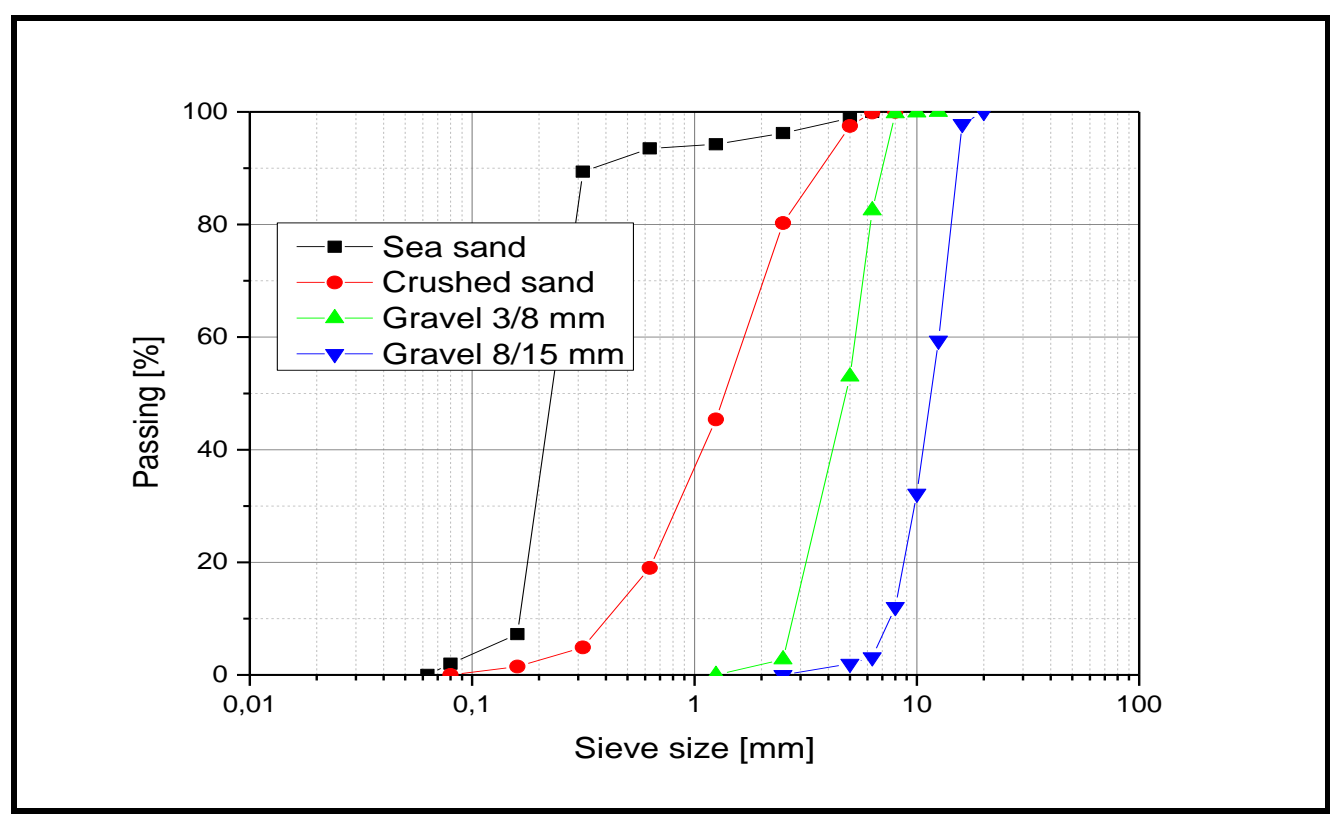

Fig 1. Particle size curves.

\section{$2.2 \quad$ Method used}

Volume substitution of class $0 / 3,3 / 8$ and 8/15 aggregates was achieved by adding wood waste particles, such as wood chips and sawdust generated from wood processing. The density values of wood and calcareous aggregates were determined by the hydrostatic weighing method. Due to the dispersion of wood density results, it was decided to use two values for the density.

Table 3. Density of materials

\begin{tabular}{|c|c|c|c|}
\cline { 2 - 4 } & MV concrete & MV $_{\text {wood 1 }}$ & MV $_{\text {wood 2 }}$ \\
\hline \hline Density $\left[\mathrm{kg} / \mathrm{m}^{3}\right]$ & 2206 & 500 & 685 \\
\hline
\end{tabular}


The quantity of wood waste used in the formulation of concrete is calculated using the following expression:

$$
M_{U W W}=\frac{\sum \text { Aggregates } \times \% \text { of substitution } \times M V_{W o o d}}{M V_{\text {concrete }}} \quad \text { Eq } 01 .
$$

Mixing is an important phase in the manufacture of light wood concrete (LWC). Since the water absorption by wood chips is very high, it was decided to use the pre-wetting method of the wood fibers to avoid water absorption during mixing. It should be noted that pre-wetting is a non-toxic and inexpensive method; it is very effective and allows reducing the loss of workability of light concrete. The mixing time of 100 seconds was considered as sufficient to obtain a homogeneous mixture of concrete.

\section{$2.3 \quad$ Formulation of concretes}

The replacement of aggregates $(3 / 8,8 / 15$ and $15 / 25)$ with wood chips was done by volume, at various percentages.

Table 2 illustrates the composition of the different types of light wood concrete.

Table 4. Composition of concretes under study

\begin{tabular}{|c|c|c|c|c|c|}
\hline \multirow{2}{*}{ Constituents $\left(\mathrm{Kg} / \mathrm{m}^{3}\right)$} & \multirow{2}{*}{$\begin{array}{l}\text { Ordinary } \\
\text { Concrete }\end{array}$} & \multicolumn{3}{|c|}{ Lightweight wood concrete "LWC" } \\
\cline { 3 - 6 } & "OC" & $10 \%$ & $20 \%$ & $10 \%$ & $20 \%$ \\
\cline { 3 - 6 } & 777 & 699.3 & 621.6 & 699.3 & 621.6 \\
\hline \hline Gravel 8/15 mm & 415 & 373.5 & 332 & 373.5 & 332 \\
\hline Gravel 3/8 mm & 372 & 334.8 & 297.6 & 334.8 & 297.6 \\
\hline Crushed sand & 1564 & 1407,6 & 1251,2 & 1407,6 & 1251,2 \\
\hline \multirow{2}{*}{$\begin{array}{c}\text { Gravel 8/15, 3/8 and } \\
\text { Crushed sand }\end{array}$} & - & $90 \%$ & $80 \%$ & $90 \%$ & $80 \%$ \\
\cline { 2 - 6 } & - & 156,4 & 312,8 & 156,4 & 312,8 \\
\hline Sea sand & 372 & 372 & 372 & 372 & 372 \\
\hline Untreated Wood Waste UWW & - & 35.5 & 70.9 & 48.6 & 97.1 \\
\hline CPJ Cement & 353 & 353 & 353 & 353 & 353 \\
\hline Total amount of water & 172 & 172 & 172 & 172 & 172 \\
\hline Slump test & S2 & S2 & S1 & S2 & S1 \\
\hline
\end{tabular}

Figure 2 gives the visual appearance of different types of light wood concrete (LWC).

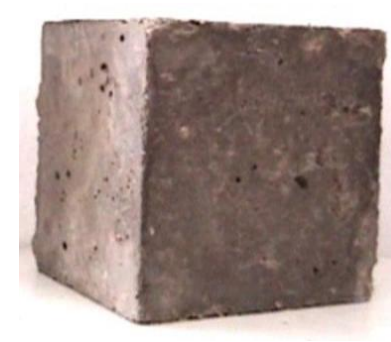

a : LWC M1 10\%

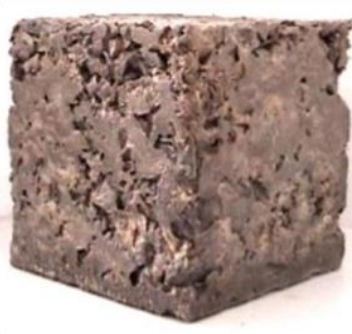

b : LWC M1 20\%

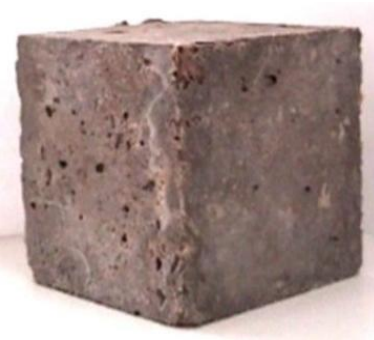

c : LWC M2 10\%

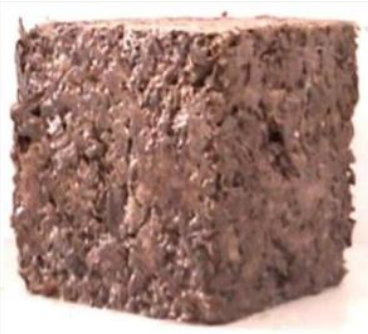

d : LWC M2 20\%

Fig 2. Lightweight wood concrete. 


\section{Results and discussion}

\subsection{Density of concrete}

During the preparation of concrete with light aggregates, a large amount of mixing water can be needed. It is important to recall that the amount of water absorbed depends on the interconnection of pores within the aggregates, on the level of initial saturation of the aggregates as well as on the water/cement $(\mathrm{W} / \mathrm{C})$ ratio of the cementitious matrix. In addition, the water absorbed by aggregates represents a reserve for the subsequent hydration of the cementitious matrix (Bentur et al., 2001; Bentz and Snyder, 1999; Kohno et al., 1999).

Figure 1 illustrates the density results of the concretes under study in the form of histograms. One may easily see that density increases when the amount of substituted granulates goes down.

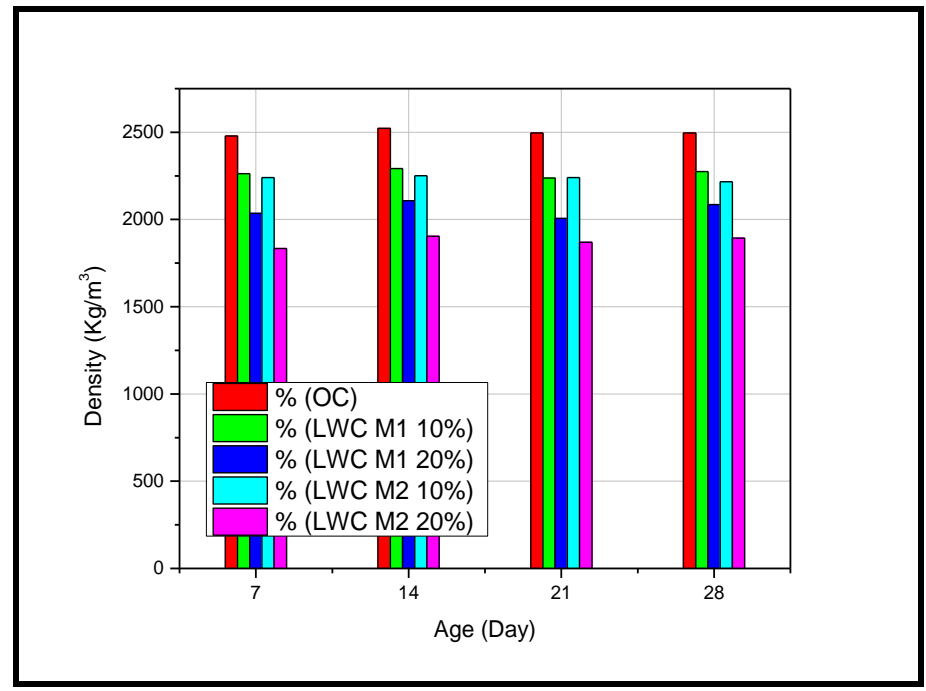

Fig 3. Density vs. Age of concrete

\subsection{Mass loss of concrete at room temperature}

Figure 4 illustrates the mass loss results of the concretes under study at room temperature. This loss of mass varies proportionally with the different substitution percentages. The results obtained indicate that the compositions produced have the characteristics of a lightweight wood-concrete (LWC) that has a density less than $2100 \mathrm{Kg} / \mathrm{m}^{3}$.

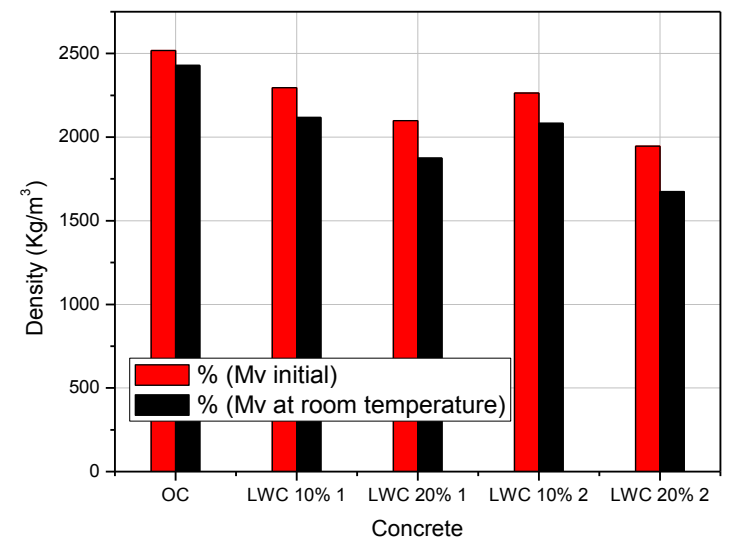

Fig 4. Percentage loss in mass of samples, at 28 days. 


\subsection{Variation of deformation as a function of applied stress}

The deformations of the specimen were measured as a function of the uniaxial compression. Two 1/100 comparators were placed on the press plate to measure the uniaxial displacement, as is clearly shown in Figure 5.

The displacements were observed on each comparator. The average of the values given by the two comparators represents the uniaxial displacement of the specimen. The deformations of specimens $7 \times 7 \times 7 \mathrm{~cm}$ were calculated using the following expression:

$$
\varepsilon=\frac{\Delta l}{L} \quad \text { Eq } 02 .
$$

- $\quad \epsilon$ : relative compressive deformation.

- $\quad \Delta \mathrm{l}$ : displacement.

- $\quad$ L: length of the test piece $7 \mathrm{~cm}$.

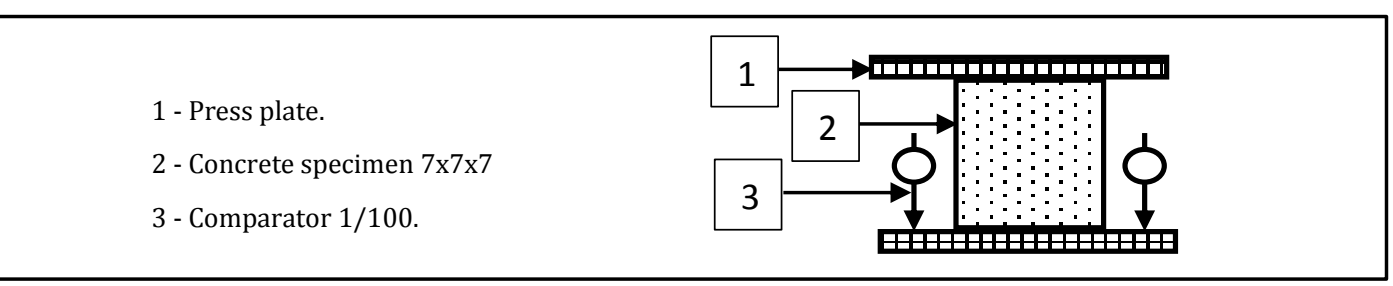

Fig 5. Apparatus used to measure the longitudinal deformations of the specimens subjected to uniaxial compression.

Figures 6, 7, 8 and 9 show the evolution of stress as a function of deformation. Specimens of dimensions (7x7x7) $\mathrm{cm}^{3}$ were made for five different types of concrete and were subjected to simple compression, at various ages, i.e. 7 days, 14 days, 21 days and 28 days. It has been found that the resistance of ordinary concrete is much higher than that of light wood concretes (LWCs) for different percentages of substitution (10\% and 20\%) and different densities (M1 and M2). It also turned out that deformation of ordinary concrete decreased steadily with age; however, different results were found for light wood concrete. The compressive strength of LWC (M2$10 \%)$ turned out to be higher than that of (M1-10\%), which in turn is higher than that of LWC (M2-20\%). Therefore, LWC (M2-20\%) proves to be the least resistant. The results obtained show that in general, though lightweight wood concrete (LWC) presents lower resistance than that of ordinary concrete $(\mathrm{OC})$, it has a better compressive strength than that of many other lightweight concretes.

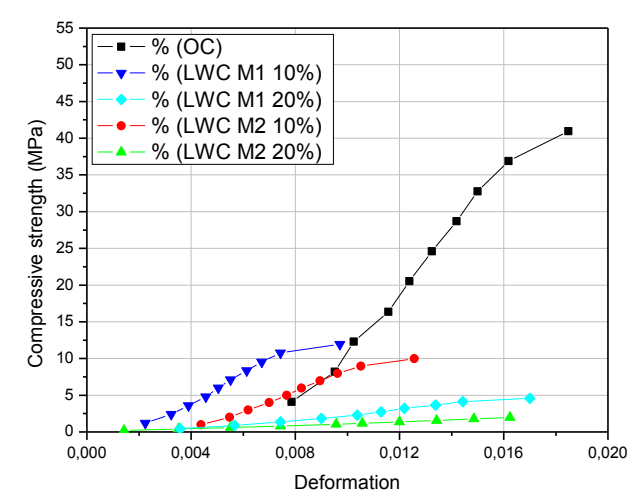

Fig 6. Evolution of the compressive strength as a function of deformation, at 7 days.

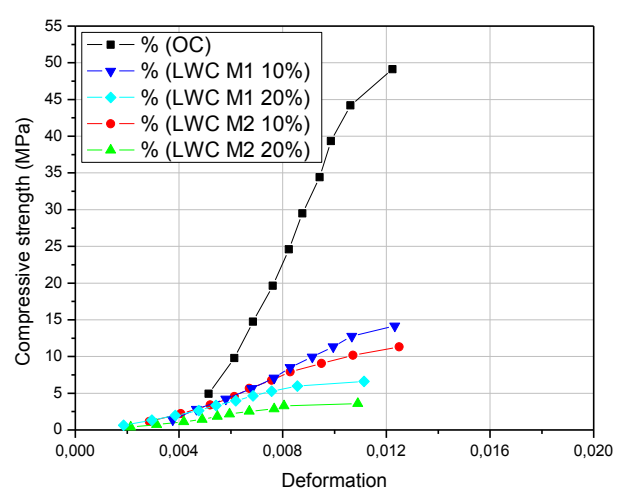

Fig 7. Evolution of the compressive strength as a function of deformation, at 14 days. 


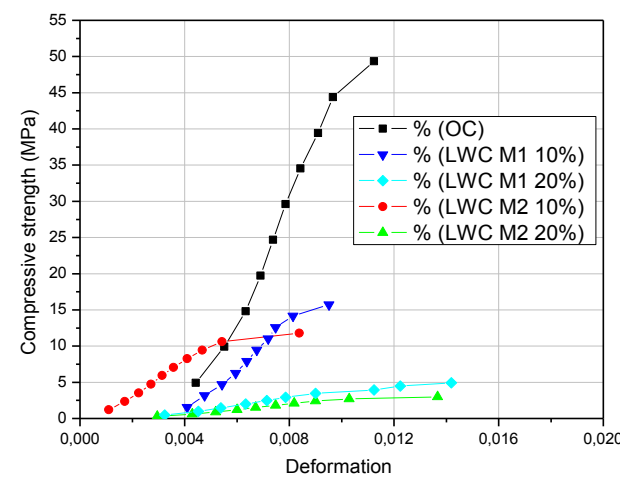

Fig 8. Evolution of the compressive strength as a function of deformation, at 21 days.

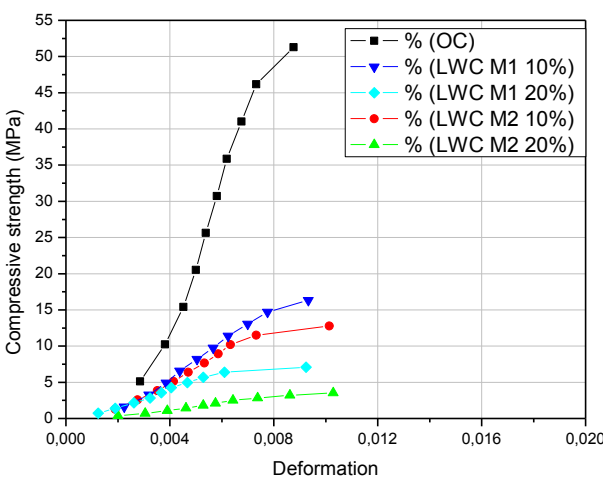

Fig 9. Evolution of the compressive strength as a function of deformation, at 28 days.

\subsection{Elastic modulus}

In the present study, the modulus of elasticity was calculated using the classical method, which consists in determining the slope of the stress/strain curve in the elastic domain.

$$
E=\frac{\sigma}{\varepsilon} \quad \text { Eq } 03 .
$$

It was found that the slope of the stress/strain curves increased for ordinary concrete, which implies a progressive increase in the elastic modulus as a function of age. On the other hand, it was noticed that the shape of the curve representing the variation of the elastic modulus of LWC (M1-10\%) is similar to that of LWC (M2-10\%); the same observation is made when comparing LWC (M1-20\%) with LWC (M2-20\%).

On the other hand, it turned out that the modulus of elasticity decreases as the percentage of substitution of aggregates rose. This was certainly due to the fact that the presence of wood waste particles has a significant impact on the mechanical characteristics of lightweight wood concrete.

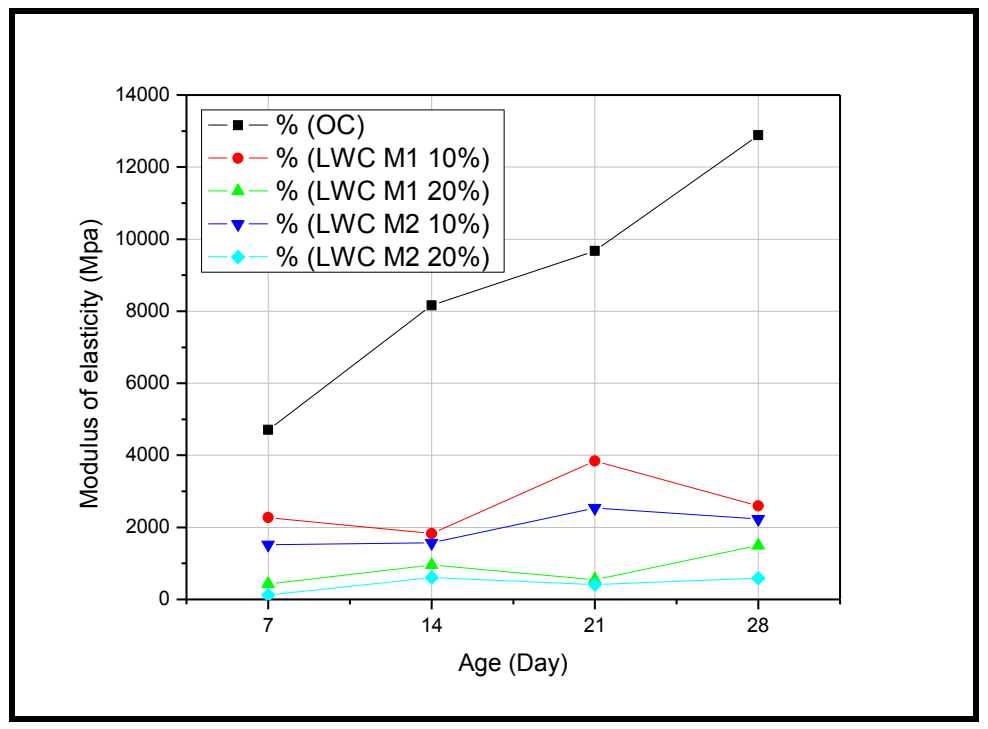

Fig 10. Evolution of the modulus of elasticity as a function of age 


\subsection{Propagation speed}

Figure 11 depicts the speed of waves propagating through different types of concrete. One may clearly note that the speed of propagation of pulses in ordinary concrete is much higher than that observed in light wood concretes, for different percentages of substitution (10\% and $20 \%)$ and for different densities (M1 and M2). The pulse propagation speed in LWC (M2-10\%) is higher than that observed in LWC (M1-10\%) in which that rate is higher than that in LWC (M2$20 \%)$.

The propagation velocity in LWC (M2-20\%) remains the lowest. In general, it may be concluded that wood waste has contributed to reducing the speed of propagation of the pulses emitted by the sonic auscultation device; which confirms the improved properties of concretes.

In addition, wood waste helped to improve the insulating properties of concrete. Indeed, the cellular structure of wood waste caused trapping of air in small volumes which represent a poor heat conductor; this is another advantage offered by lightweight wood concrete in thermal insulation.

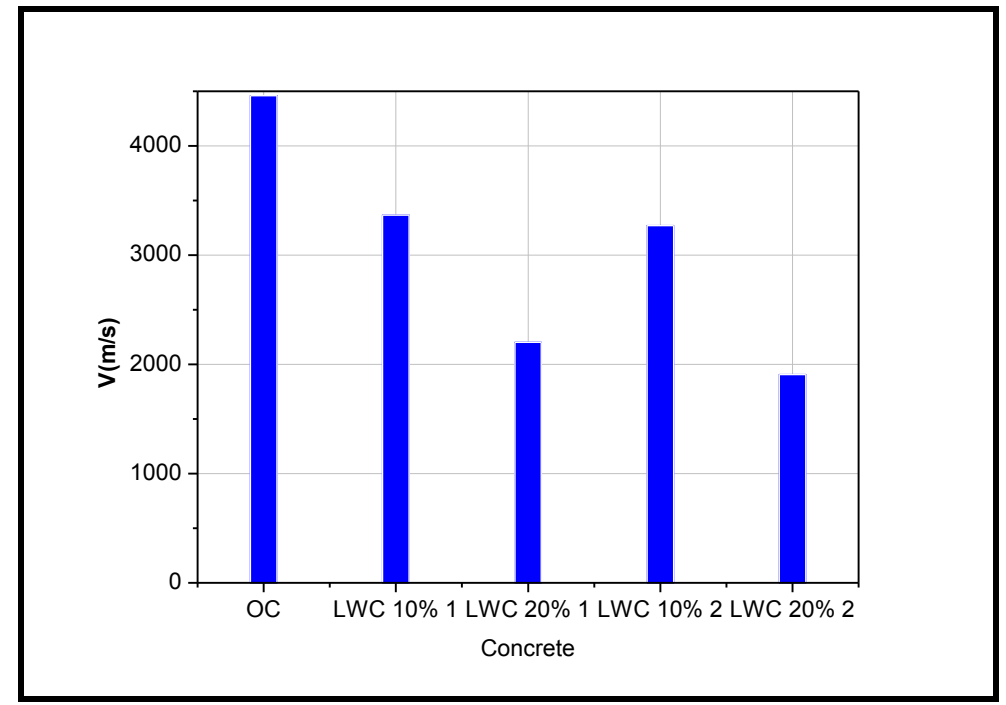

Fig. 11. Pulse propagation speed in concrete, at 28 days.

\section{Conclusion}

This experimental study made it possible to highlight the influence of wood waste from industry on the mechanical properties of ordinary concrete. Volumes of gravel of classes 8/15, 3/8 and $0 / 3$ were replaced by wood waste at two percentages $(10 \%$ and $20 \%)$ to obtain light wood concrete (LWC). The main conclusions of this study are summarized in the following points:

- Light wood concrete (LWC) has a very good compressive strength in comparison with other types of light concrete but is less resistant to compression as compared to other concretes. However, its properties give it a great advantage to be developed and used in the construction field. From an environmental point of view, this would help to get rid of wood waste.

- In addition, the stress/strain curves made it possible to follow and control the behavior of concretes in the elastic and post-elastic regions, where it was found that the elastic phase ends between 80 and $90 \%$ of the resistance to compression, whatever the type of concrete used.

- Furthermore, the modulus of elasticity was calculated using the stress/strain curve in the elastic region. The curve representing the evolution of the elastic modulus of 
light wood concretes shows an irregularity that is mainly due to the heterogeneity of wood waste.

- wood waste has increased the insulating properties of concrete, which in turn reduced the speed of propagation of pulses. This behavior is attributed to the cellular structure of wood waste that traps air in the form of small volumes.

- The behavior of light wood concrete (LWC) in the fresh state can be mastered only in precast concrete plant to control its strength and vibration time. Our main prospect is to improve the behavior of light weight concrete (LWC) in the fresh state by using appropriate superplasticizers to obtain class S3 or S4 concretes according to the recommended specifications and in order to respect the international Standards. A concrete screed may be taken as an example in this case.

\section{References}

Akkaoui, A. (2014). Bétons de granulats de bois: Étude expérimentale et théorique des propriétés thermohydro-mécaniques par des approches multi-échelles. Doctoral dissertation, école doctorale science ingénierie et environnement, Université paris-est, France.

Benmalek, L., \& Bederina, M. (2014). Les performances mécaniques et thermiques d'un béton léger à base de déchets industriels solides et de granulats de bois. In MATEC Web of Conferences (Vol. 11, p. 01040). EDP Sciences.

Bentur, A., Igarashi, S. I., \& Kovler, K. (2001). Prevention of autogenous shrinkage in high-strength concrete by internal curing using wet lightweight aggregates. Cement and concrete research, 31(11), 1587-1591.

Bentz, D. P., \& Snyder, K. A. (1999). Protected paste volume in concrete: Extension to internal curing using saturated lightweight fine aggregate. Cement and concrete research, 29(11), 1863-1867.

Bouabdallah, M.A., (2008). Valorisation des déchets de bois. 1er Colloque Euromaghrébin sur les Bois Méditerranéens Caractérisation et valorisation technologique des bois résineux méditerranéens ; Université M’Hamed Bougara de Boumerdès, 30 mars au 2 avril, Algeria.

Bouabdallah, M.A., et al. (2007). Comportement du béton léger à base de granulats et des fibres de bois ; Séminaire national de «Génie Civil », Université Badji Mokhtar - Annaba Faculté des Sciences de l'Ingénieur, Département de Génie Civil \& Laboratoire de Génie Civil, 20 \& 21 Novembre, Algeria.

Bouabdallah, M.A., et al. (2007). Etude comparative des bétons légers à base des granulats et des déchets de bois non traites et un béton ordinaire ; Séminaire national sur " La Gestion intégrée des déchets » organisé par l'Ecole Normale Supérieure d'Enseignement Technique, E.N.S.E.T. d'ORAN, 29 \& 30 Mai, Algeria.

Bouaziz., S., \& Ait Tahar., K. (2014). Elaboration et Caractérisation d'un Béton Composite à Granulats Composites., 82 ème Congrès de L'ACFAS., Université concordia - Quebec du 12 au 16 Mai.

Breitenbiicher, R. (1998). Developments and applications of high performance concrete. Materials and Structures, 31, 209-215.

Hadjoudja, M., \& Bederina, M. (2005). Influence des fillers des déchets de briques sur la durabilité à l'eau du béton de sable de dunes, Laboratoire de Génie Civil, Institut de Génie Civil, Université de Laghouat, Colloque CMEDIMAT 2005, Algeria.

Jiang, Y., Ling, T. C., \& Shi, M. (2020). Strength enhancement of artificial aggregate prepared with waste concrete powder and its impact on concrete properties. Journal of Cleaner Production, 257, 120515.

Kalpana, M., \& Tayu, A. (2020). Experimental investigation on lightweight concrete added with industrial waste (steel waste). Materials Today: Proceedings, 22, 887-889.

Kohno, K., Okamoto, T., Isikawa, Y., Sibata, T., \& Mori, H. (1999). Effects of artificial lightweight aggregate on autogenous shrinkage of concrete. Cement and concrete research, 29(4), 611-614. 
Medjelekh, D., Ulmet, L., \& Dubois, F. (2014). Mesure et modélisation des transferts hygrothermiques d'une enveloppe en béton de bois'. Conférence IBPSA, Arras, France.

Mohammadhosseini, H., Alyousef, R., Lim, N. H. A. S., Tahir, M. M., Alabduljabbar, H., \& Mohamed, A. M. (2020). Creep and drying shrinkage performance of concrete composite comprising waste polypropylene carpet fibres and palm oil fuel ash. Journal of Building Engineering, 30, 101250.

Oredsson, J. (1997). Tendency to spalling of high strength concrete. Interim Report M, 7(4), Skanska, np 30.

Taazount, M., Amziane, S., Moutou-Pitti, R., \& Molard, D. (2011). Elément de Planchers Composites BoisBéton Léger ; 20 ème Congrès français de mécanique. AFM, Maison de la Mécanique, 39/41 rue Louis Blanc, 92400 Courbevoie, France.

Zeghichi, L., Merzougui, A., \& Chabi, S., (2005). L'influence des déchets de verre sur les propriétés du béton, Colloque CMEDIMAT 2005, Université de M'sila, Algeria. 